\title{
PERBANDINGAN EFEKTIFITAS CHAINSAW STIHL 070 DAN STIHL MS 381 PADA KEGIATAN PENEBANGAN POHON
}

\author{
Rochmad Hidayat $^{1}$, Wiyono ${ }^{2}$ dan Silvi Nur Oktalina ${ }^{3}$ \\ ${ }^{1}$ Program Studi Diploma III Pengelolaan Hutan Sekolah Vokasi UGM. Email: rochmad.hidayat@ugm.ac.id \\ ${ }^{2}$ Program Studi Diploma III Pengelolaan Hutan Sekolah Vokasi UGM. Email: wiyono.putro@ugm.ac.id \\ ${ }^{3}$ Program Studi Diploma III Pengelolaan Hutan Sekolah Vokasi UGM. Email: silvi.nuroktalina@ugm.ac.id
}

\begin{abstract}
Felling is an important aspect in forest management. The effectiveness of felling affects forest management, wood harvesting in particular. For that reason, it is highly needed to understand the effectiveness of using different chainsaws for felling the trees. The purpose of this research is to know the effectiveness and work performance of chainsaw Stihl MS 381 and 070 on felling activities. This research was conducted in KPH Ngawi Perum Perhutani regional division of East Java with Swietenia macrophllya as its forest stand. Then, work time and work result on wood harvesting obtained was taken as research data employing repetitive timing method. Data analysis was conducted by calculating the work result, calculating the volume using Wood Volume Table for mahogany (tabel isi kayu mahoni) and applying $T$ test for testing the significant difference of working performance between Stihl MS 381 and 070. Based on this research, the work performance of chainsaw MS 381 was 1,42 $\mathrm{m}^{3} /$ hour or $11,33 \mathrm{~m}^{3} /$ day work and for chainsaw 070 was $1,83 \mathrm{~m}^{3} /$ hour or $14,63 \mathrm{~m}^{3} /$ day work. Both sthil MS 381 and 070 chainsaw performed similar work effectiveness to finish the felling of mahogany stands. It was clearly proved by their work time and work performance which were not much different.
\end{abstract}

Keywords: harvesting, felling, work performance, effectiveness

\section{PENDAHULUAN}

Penebangan merupakan komponen penting dalam kegiatan pemanenan hasil hutan kayu. Penebangan menjadi kegiatan kedua dalam proses pemanenan hasil hutan kayu setelah perencanaan. Conway (1982) menjelaskan bahwa elemen kegiatan pemanenan hasil hutan kayu terdiri dari: perencanaan pemanenan; penebangan dan pembagian batang; penyaradan; pemuatan; pengangkutan; pembongkaran; dan pembangunan jalan. Menurut Sessions (2007), penebangan merupakan langkah pertama dalam proses mengkonversi pohon menjadi produk hutan yang lainnya. Hal tersebut menegaskan bahwa kegagalan dalam kegiatan penebangan mengakibatkan tersendatnya porses pemanenan hasil hutan kayu. Penebangan menjadi salah satu penentu kualitas kayu yang diproduksi. Kesalahan dalam penebangan dan kesalahan dalam pembagian batang akan sangat berpengaruh terhadap kualitas kayu yang dihasilkan. Kesalahan-kesalahan tesebut dapat mengakibatkan kerusakan pada kayu hasil tebangan bahkan dapat mengakibatkan kayu yang ditebang tidak dapat diproses lebih lanjut. Kegiatan penebangan dan pembagian batang yang efektif dan efisien diperlukan dalam pemanenan hasil hutan kayu.

Efektifitas penebangan salah satunya dipengaruhi oleh peralatan yang digunakan. MacDonald (1999) menjelaskan bahwa pemilihan alat yang tidak tepat akan menyebabkan tujuan yang diinginkan dalam pemanenan hasil hutan kayu tidak akan tercapai. Dijelaskan lebih lanjut bahwa ketidaksesuaian peralatan yang digunakan dalam kegiatan pemanenan akan mengakibatkan kondisi yang tidak aman dan biaya pemanenan yang tinggi. Kondisi yang tidak aman dan biaya yang tinggi akan berakibat pada kegiatan pemanenan yang tidak efektif dan efisien. Pemilihan alat yang tepat pada kegiatan penebangan menjadi penting untuk dapat meningkatkan keaaman kerja dan efektifitas penebangan pohon. 
Peralatan penebangan pohon yang digunakan di Indonesia memiliki speseifikasi yang sama meskipun objek yang dihadapi berbeda. Dijelaskan oleh MacDonald (1999) bahwa salah satu factor yang berpengaruh dalam pemilihan peralatan pemanenan dalah karateristik pohon/tegakan. Objek tebangan yang berbeda tentu saja akan berpengaruh pada kareteristik pohon yang berbeda. Dibutuhkan alat yang berbeda untuk dapat menyelsaikan tebangan dengan meminimalkan resiko kecelakan kerja, resiko kerusakan lingkungan dan resiko kerusakan hasil tebangan. Sayangnya di Indonesia khususnya di Perum Perhutani disetiap kegiatan penebangan selalu menggunakan alat yang sama (Stihl 070) meskipun karateristik tegakan yang dihadapi berbeda. Alat yang digunkan pun belum mempunyai standar keamanan yang memadai. Berdasarkan hal penelitian ini dilakukan dengan harapan dapat memberikan data yang akurat sebagai bahan pertimban pertimbangan dalam pemilihan alat penebangan. Tujuan dari penelitian ini adalah untuk menghitung prestasi kerja alat penebangan Chain Saw Sthil 070 dan Sthil MS 381 dan mengetahui efektifitas kerja kedua alat tersebut pada kegiatan penebangan di Perum Perhutani.

\section{BAHAN DAN METODE PENELITIAN}

Penelitian ini dilakukan pada bulan Maret-Oktober 2017 di petak 65D RPH Gelon BKPH Sonde KPH Ngawi Perum Perhutani Devisi Regional Jawa Timur dengan jenis Mahoni. Topografi dan kareteristik tegakan pada petak tebangan cukup seragam. Bahan yang digunkan pada penelitian ini adalah tegakan mahoni dan satu set kegiatan penebangan tegakan tersebut. Kegiatan tebangan yang digunakan sebagai bahan dalam penelitian ini adalah mulai dari persiapan sampai dengan pembagian batang.

Alat penebangan yang digunakan dalam penelitian ini adalah chainsaw merk Stihl 070 dan Stihl MS 381. Sepesifikasi Stihl 070 adalah mesin dua tak (dua langkah) $106 \mathrm{cc}$, kekuatan mesin 4,8 kW, panjang bilah pemotong $90 \mathrm{~cm}$, kecepatan maksimum $7.500 \mathrm{rpm}$ dan berat kering mesin $10,7 \mathrm{Kg}$ (Manual Stihl 070, 090). Spesifikasi Stihl MS 381 adalah mesin sua tak (dua langkah) 72,2 cc, kekuatan mesin 3,9 kW, panjang bilah pemotong $40 \mathrm{~cm}$, kecepatan standar $2.800 \mathrm{rpm}$ dan berat kering mesin $6,6 \mathrm{Kg}$ (Manual Stihl MS 381). Bahan bakar kedua alat tersebut adalah bensin yang dicampur dengan pelumas, kemudian untuk pelumas mesin menggunakan pelumas mesin bekas. Operator chainsaw (Blandong) adalah mitra Perum Perhutani yang ditugaskan pada petak tebangan sesuai dengan berita acara penebangan. Kemampuan blandong tersebut telah memenuhi standar dari Perum Perhutani untuk bekerja pada kegiatan penebangan.

Data diambil dengan pengamatan dilapangan, pengukuran dan wawancara. Pengamatan dailakukan pada proses kegiatan penebangan pohon dan pembagian batang. Pengamatan tersebut sekaligus dilakukan perhitungan waktu kerja mulai dari awal sampai dengan berakhirnya kegiatan penebangan pohon dan pembagian batang. Penghitungan waktu kerja dilakukan dengan metode repetitive timing method, yaitu dengan mencatat waktu kerja di setiap elemen kerja yang dilakukan dalam satu kegiatan. Waktu kerja masing-masing elemen dihitung menggunakan stopwatch. Digunakan cara perhitungan waktu kerja tersebut diharapakan akan mendapatkan data waktu secara detail di setiap elemen kegiatan baik penebangan maupun pembagian batang sehingga akan memudahkan pada saat analisis data dan penarikan kesimpulan. Volume hasil tebangan (hasil kerja) ditentukan sesuai dengan perhitungan yang dilakukan oleh Perum Perhutani yaitu dengan menggunakan table isi kayu Mahoni. Tabel tersebut menggunakan pembuka berupa diameter terkecil dari setiap log yang ditebang.

Pengambilan data waktu kerja dan hasil kerja dilakukan pohon per pohon dan alat per alat. Dihitung dan diukur satu pohon sampai dengan selesai baru kemudian pindah pada pohon yang lainnya. Begitu pula dengan alat yang digunakan, menggunakan satu alat terlebih dahulu sampai dengan kecukupan data baru kemudian berganti dengan alat yang lainnya. Hal tersebut dilakukan untuk menghindarkan kesalahan dalam perhitungan waktu kerja dan kerancuan dalam pengukuran hasil kerja. Hasil pencatatan waktu kerja dan hasil kerja dari masing-masing alat tersebut dilakukan perhitungan untuk mengetahui prestasi kerja masing-masing alat. Berikut ini adalah tahapan perhitungan tersebut: 


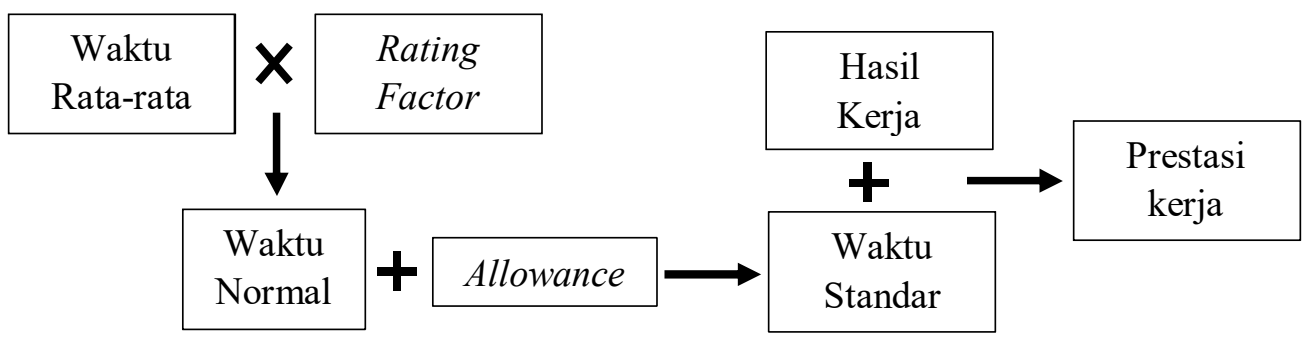

Rating factor yang digunakan dalam penelitian ini menggunakan metode Westinghouse yang ditentukan nilainya berdasarkan kondisi lokasi penelitian baik kondisi lapangan maupun kondisi operator tebangan. Digunakan metode tersebut dikarenakan dapat menggambarkan kondisi riil dilapangan yang berpengaruh terhadap kegiatan penebangan dan pembagian batang. Waktu allowance dihitung sesuai dengan kondisi yang sebenarnya terjadi pada saat penelitian. Berdasarkan Bjorheden and Thompson (2000), allowance dapat dimasukkan dalam Work-Related Delay Time (WD) dimana merupakan bagian dari non-work time yaitu waktu kerja yang dimana tidak ada pekerjaan yang ditujukan untuk menyelsaikan tugas/beban kerja yang telah direncanakan. Dijelaskan lebih lanjut bahwa allowance dapat berasal dari waktu istirahat, makan dan kegiatan menunggu selsainya kegiatan lain yang saling bergantung satu dengan yang lainnya. Data prestasi kerja dari masin-masing alat yang digunakan dianalisis secara statistik untuk mengetahui ada tidaknya perbedaan nyata diantara dua prestasi kerja tersebut.

\section{HASIL DAN PEMBAHASAN}

Sampel yang digunakan dalam penelitian ini adalah sebanyak 32 pohon untuk Stihl MS 381 (alat 1) dan 30 pohon untuk Stihl 070 (alat 2). Jumlah tersebut dianggap telah mampu menggambarkan performa blandong dalam melaksanakan pekerjaanya dan mampu menggambarkan kinerja alat yang digunakan. Total hasil kerja dari kedua alat yang digunakan dalam penelitian ini adalah sebanyak $92,53 \mathrm{~m}^{3}$ dengan rata-rata volume tiap pohon adalah $1,49 \mathrm{~m}^{3}$. Total hasil kerja chainsaw Stihl MS 381 adalah sebanyak $45,3 \mathrm{~m}^{3}$ dengan rata-rata tiap pohon adalah sebanyak $1,41 \mathrm{~m}^{3}$. Sedangkan untuk Stihl 070 total hasil kerja adalah sebanyak $47,3 \mathrm{~m}^{3}$, dengan rata-rata tiap pohon adalah sebesar $1,58 \mathrm{~m}^{3}$.

Berdasarkan pengamatan prilaku kerja blandong diperoleh 15 elemen kerja. Elemen kerja adalah tahapan kerja yang dilakukan pekerja untuk menyelsaikan kegiatannya. Elemen kerja tersebut mulai dari persiapan alat sampai dengan allowance. Seluruh elemen kerja beserta waktu kerja hasil pengamatan disajikan pada Gambar 1. Hasil pengamatan menunjuukkan bahwa waktu kerja terbanyak terjadi pada elemen kerja pemotongan batang. Pemotongan batang adalah kegiatan membagi batang pohon yang telah ditebang kedalam beberapa sortimen sesuai dengan kondisi pohon. Waktu kerja pemotongan batang yang dihasilkan dengan menggunakan chainsaw Stihl 070 adalah 9,31 menit sedangkan Stihl MS 381 adalah selama 14,12 menit. Waktu kerja tercepat adalah penentuan arah rebah pohon. Arah rebah pohon ditentukan berdasarkan kondisi pohon, arah angin dan kondisi topogarafi lokasi tebangan. Waktu kerja menentukan arah rebah untuk alat 1 adalah 0,22 menit dan alat 2 adalah 0,19 menit. Elemen kerja mengecek kondisi alat hanya dilakukan pada alat 1 saja, untuk alat 2 selama dilaksanakan penelitian tidak dilakukan pengecekan alat. 


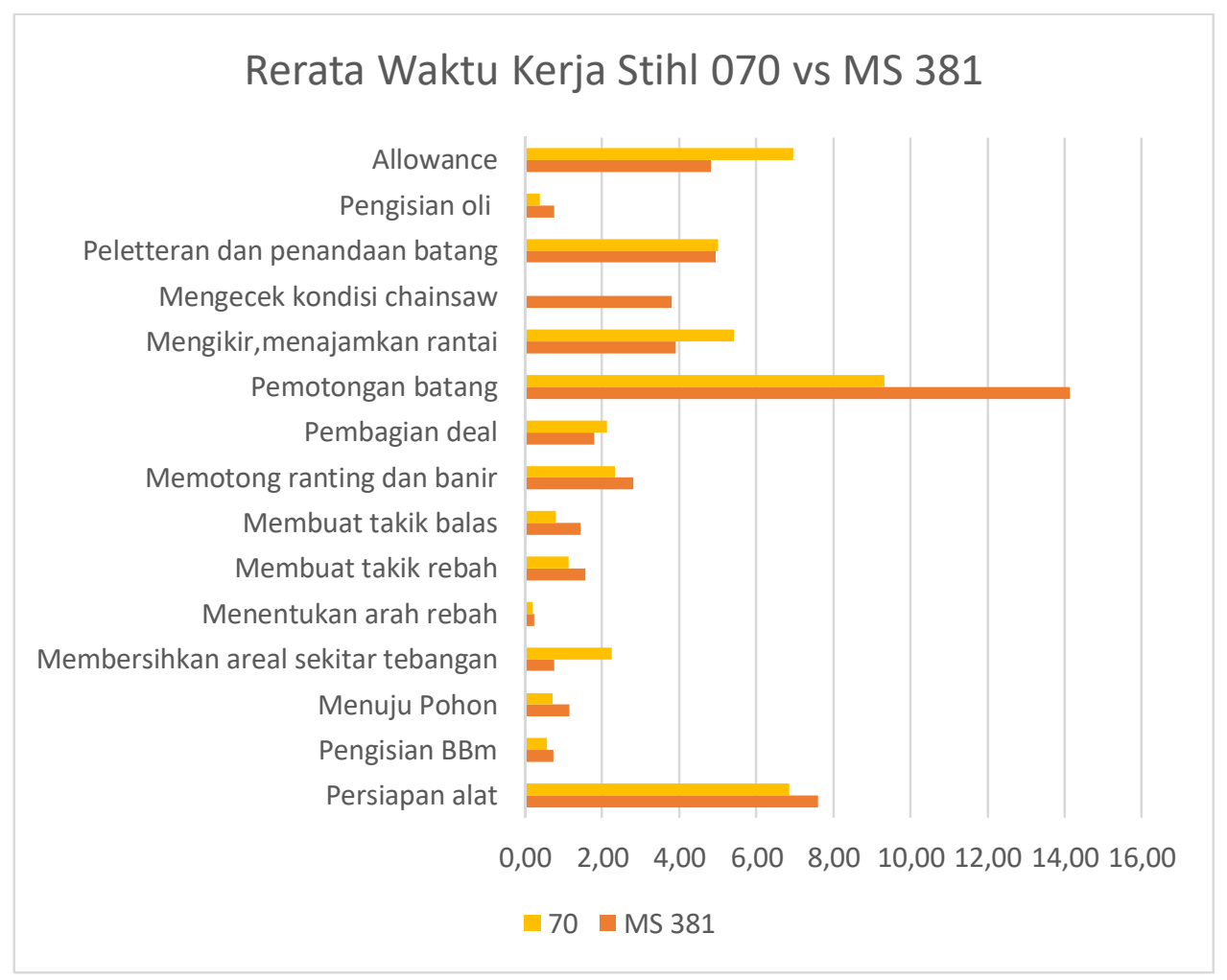

Gambar 1. Grafik waktu kerja pada setiap elemen kerja.

Mengacu pada pembagian waktu menurut Komite Prestasi Kerja IUFRO (Bjorheden and Thompson, 2000), elemen kerja pada penelitian ini dapat dibagi menjadi elemen kerja utama, elemen kerja pelengkap dan elemen kerja pendukung. Berdasarkan tujuan dari penelitian ini kegiatan yang termasuk dalam elemen kerja utama adalah, membuat takik rebah; membuat takik balas; memotong ranting dan banir; dan pemotongan batang. Sedangkan kegiatan yang termasuk dalam elemen kerja pelengkap adalah, menuju pohon; membersihkan areal sekitar tebangan; menentukan arah rebah; pembagian deal;dan peletteran dan penandaan batang. Kemudian kegiatan yang termasuk dalam elemen kerja pendukung adalah persiapan alat; pengisian BBM, pengecekan kondisi chainsaw; dan pengisian oli/pelumas. Allowance tidak termasuk dalam elemen kerja akan tetapi allowance termasuk dalam klasifikasi bukan waktu kerja (non-work time).

Rating factor yang digunakan dalam penelitian ini adalah sebesar 1,21. Nilai tersebut diperoleh dari sistem rating factor Westinghouse. Sistem tersebut didasarkan pada 4 faktor, yaitu ketrampilan, usaha, kondisi dan kosistensi. Berdasarkan hasil pengamatan selama penelitian ketrampilan blandong dinilai baik sekali, usaha dinilai baik, kondisi dinilai baik dan konsistensi dilinali baik sekali. Sehingga diperoleh nilai total adalah $+0,21$. Hal tersebut berarti bahwa waktu kerja yang dibutuhkan oleh blandong untuk menyelsaikan pekerjaanya lebih cepat $21 \%$ dibandingkan dengan waktu yang dianggap normal untuk meyelsaiakan pekerjaan blandong. Oleh karena itu utuk memperoleh waktu normal dalam penelitian ini waktu kerja rata-rata yang dihasilkan oleh blandong harus ditambahkan dengan $21 \%$ dari waktu rata-rata tersebut. Sehingga diperoleh rating factor sebesar 1,21. Rating factor tersebut berlaku untuk kedua alat yang digunakan dalam penelitian ini karena blandog yang melaksanakan perkejaan penebangan dan pembagian batang adalah sama.

Waktu normal yang dihasilkan blandong dengan alat 1 adalah sebesar 55,09 menit sedangkan untuk alat 2 diperoleh waktu selama 44,78 menit. Waktu normal tersebut diperoleh dari total seluruh waktu yang dihasilkan di setiap elemen kerja. Waktu normal menunjukkan waktu yang diperlukan oleh pekerja untuk menyelsaikan pekerjaanya dimana pekerja tersebut tidak terlalu ahli juga tidak 
terlalu amatir. Waktu standar yang diperoleh dari hasil pengamatan untuk alat 1 adalah selama 59,90 menit sedangkan untuk alat 2 adalah selama 51,73 menit. Waktu standar menunjukkan waktu idela bagi pekerja untuk menyelsaikan tugasnya. Berdasarkan waktu standar tersebut diperoleh prestasi kerja blandong dengan tiap alat yang digunakan yaitu sebesar $1,42 \mathrm{~m}^{3} / \mathrm{jam}$ untuk alat 1 sedangkan untuk alat 2 sebesar $1,83 \mathrm{~m}^{3} / \mathrm{jam}$. Apabila waktu kerja dalam 1 hari adalah 8 jam, maka diperoleh prestasi kerja sebesar $11,33 \mathrm{~m}^{3} /$ hok untuk alat 1 dan 14,63 untuk alat 2 .

Prestasi kerja tersebut di atas dihitung dengan waktu seluruh elemen kerja yang dilakukkan oleh pekerja. Apabila prestasi kerja tersebut dihitung hanya dengan elemen kerja utama maka akan diperoleh hasil yang berbeda. Hal ini dilakukan karena tujuan dari penelitian ini adalah untuk menilai prestasi kerja kedua alat yang digunakan sehingga perlu dilihat lebih detail kinerja alat tersebut. Berdasarkan perhitungan prestasi kerja pada elemen kerja utama diperoleh waktu normal selama 24,11 menit dan waktu standar 28,91 menit untuk alat 1 sedangkan untuk alat 2 diperoleh waktu normal selama 22,75 dan waktu standar 29,70 menit. Prestasi kerja untuk alat 1 dan 2 berturut-turut adalah

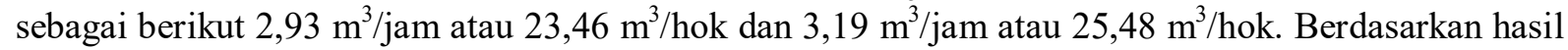
tersebut diketahui bahwa prestasi kerja alat 2 lebih besar dibandingkan dengan prestasi kerja alat 1 . Perbedaan tersebut terjadi karena rata-rata hasil kerja alat 2 lebih besar dibandingkan dengan alat 1 . Sehingga meskipun waktu standar alat 1 lebih cepat daripada alat 2, prestasi kerja alat 2 lebih tinggi. Namun demikian perbedaan tersebut tidak begitu signifikan yaitu sebesar $2,02 \mathrm{~m}^{3} /$ hok.

Tabel 1. Hasil Perhitungan Prestasi Kerja

\begin{tabular}{lrrrr}
\hline & \multicolumn{2}{c}{ Waktu Total } & \multicolumn{2}{c}{ Elemen Kerja Utama } \\
& Stihl MS 381 & \multicolumn{1}{c}{ Stihl 070 } & Stihl MS 382 & \multicolumn{1}{c}{ Stihl 070 } \\
\hline WN (menit) & 55.09 & 44.78 & 24.11 & 22.75 \\
WS (menit) & 59.90 & 51.73 & 28.91 & 29.70 \\
PK $_{\mathbf{1}}\left(\mathbf{m}^{\mathbf{3}} / \mathbf{J a m}\right)$ & 1.42 & 1.83 & 2.93 & 3.19 \\
PK $_{\mathbf{2}}\left(\mathbf{m}^{\mathbf{3}} / \mathbf{h o k}\right)$ & 11.33 & 14.63 & 23.46 & 25.48
\end{tabular}

Keterangan : WN (Waktu Normal); WS (Waktu Standar); $\mathrm{PK}_{1}$ (Prestasi Kerja/Jam); $\mathrm{PK}_{2}$ (Pertasi kerja/hari kerja/8 jam); Waktu Kerja Total (waktu kerja untuk seluruh elemen kerja); Elemen Kerja Utama (waktu kerja hanya untuk elemen kerja utama)

Berdasarkan analisis beda nyata antara rata-rata waktu kerja seluruh elemen kerja alat 1 dan alat 2 dengan tingkat kepercayaan 95\% diperoleh hasil yang tidak signifikan. Hal tersebut dibuktikan dengan nilai signifikansi hasil uji adalah sebesar 0,378 lebih besar dari 0,05 sehingga Ho diterima (hasil uji secara lengkap disajikan pada tabel 2. Hipotesis yang digunakan dalam pengujian ini adalah sebagai berikut, Ho adalah tidak ada perbedaan rata-rata waktu kerja di seluruh elemen kerja antara alat 1 (MS 381) dengan alat 2 (070) dan Ha adalah terdapat perbedaan rata-rata waktu kerja di seluruh elemen kerja antara alat 1 (MS 381) dengan alat 2 (070). Hasil tersebut membuktikan bahwa tidak ada perbedaan waktu kerja yang nyata antara alat 1 dan alat 2, sehingga baik alat 1 dan alat 2 mempunyai performa yang sama untuk bisa menyelsaikan pekerjaannya.

Tabel 2. Hasil Analisis Beda Nyata dengan Uji T

\begin{tabular}{lccccc}
\hline Paired Samples Test & & & & \\
& & Paired Differences & \multicolumn{1}{l}{} & df & Sig. (2-tailed) \\
\hline Pair 1 & MS381 - Stihl070 & 1.42778 & 0.91 & 14 & 0.378 \\
\hline
\end{tabular}

Keterangan: tingkat kepercayaan pengujian sebesar 95\%

Berdasarkan wawancara dengan blandong performa alat 1 dan alat 2 relatif sama. namun demikian kedua alat tersebut masing-masing alat mempunya kelebihan dan kekurangan. Kelebihan dari alat 1 adalah, mudah mengoperasikannya karena alat cukup ringan sehingga untuk pindah posisi ke pohon yang lain lebih mudah dan cepat, tenaga yang dibutuhkan untuk menggendalikan alat lebih kecil 
apabila dibandingkan dengan alat 2. Kekurangan dari alat 1 adalah apabila dingunakan pada pohon diameter besar perlu teknik khusus karena panjang bilang pemotong lebih pendek dibandingkan dengan alat 2 dan karena tangki bahan bakar berkapasistas kecil makan akan sering mengisi bahan bakar namun demikian konsumsi bahan bakar diantara kedua alat tersebut tidak jauh berbeda yaitu 15,20 liter untuk alat 1 dan 15,60 liter untuk alat 2. Dapat dikatakan bahwa alat 1 lebih irit daripada alat 2 dengan beban kerja hampir sama yaitu menebang 32 dan 30 pohon. Kelebihan dari alat 2 adalah alat 2 lebih mudah digunakan pada pohon berdiameter besar dibandingkan dengan alat 1 dan pengisisan bahan bakar tidak terlalu sering sedangkan kekurangnnya adalah beban yang lebih berat membuat blandong membutuhkan tenaga yang lebih besar untuk mengendalikannya dibandingkan dengan alat 1 .

Tabel 3. Konsumsi BBM dan Pelumas Masing-masing Alat

\begin{tabular}{lrr}
\hline & Stihl MS 381 & Stihl 070 \\
\hline Jumlah Sampel & 32 & 30 \\
BBM (liter) & 0.48 & 0.52 \\
Pelumas (liter) & 0.14 & 0.14 \\
\hline
\end{tabular}

Berdasarkan hasil perhitungan waktu kerja, prestasi kerja dan wawancara dengan blandong dapat dikatakan bahwa tidak terdapat perbedaan performa dianatar alat 1 dan alat 2 . Hal tersebut megindikasikan bahwa alat 1 dapat digunakan dalam kegiatan penebangan di Perum Perhutani tanpa mengurangi prestasi kerja. Selain hal tersebut alat 1 mempunyai fitur keamanan yang lebih bagus dibandingkan dengan alat 2, karena alat 1 memiliki rem rantai (chain brake) sehingga lebih aman, sewaktu-waktu ingin menghentikan laju rantai dapat dilakukan dengan rem tesebut.

\section{KESIMPULAN}

Berdasarkan hasil penelitian yang dilakukan dapat ditarik kesimpulan sebagai berikut:

1. Prestasi kerja chainsaw Stihl MS 381 sebesar $1,42 \mathrm{~m}^{3} / \mathrm{jam}$ atau $11,33 \mathrm{~m}^{3} /$ hok dan prestasi kerja chainsaw Stihl 070 sebesar $1,83 \mathrm{~m}^{3} / \mathrm{jam}$ atau $14,63 \mathrm{~m}^{3} /$ hok.

2. Chainsaw Sthil MS 381 dan 070 mempunyai efektifitas kerja yang relatif sama dalam menyelsaikan pekerjaan penebangan tegakan mahoni, hal tersebut dibuktikan dengan waktu kerja dan prestasi kerja yang tidak jauh berbeda.

\section{UCAPAN TERIMAKASIH}

Ucapan terimakasih kami sampaikan kepada seluruh pihak yang membantu pelaksanaan penelitian ini mulai dari awal hingga akhir. Terimakasih kepada Bagas, Najieh, Ayta yang telah membantu mengambil data di lapangan. Terimakasih kepada Bapak Agus Ahmad Fadholi, Jhon Sapulete dan Sudarsono yang telah memberikan ijin dan memfasilitasi pengambilan data di lapangan. Terimakasih kepada regu kerja penebangan petak 65 D RPH Gelon, BKPH Sonde KPH Ngawi. Terimaksaih juga kami sampaikan kepada seluruh Civitas akademika di Sekolah Vokasi UGM yang telah memberikan kesempatan dan fasilitas untuk bisa terlaksananya penelitian ini.

\section{DAFTAR PUSTAKA}

Bjorheden, R. dan Thompson, M. A., (2000). An International Nomenclature For Forest Work Study, dalam Field, D.B. (ed), Prosiding, IUFRO 1995 S3.04.02, Konggres Dunia XX, 6-12 Agustus 1995, Tampere, Finlandia. University of Maine. Orono, Maine 04469-5755,USA

Conway, S. (1982). Logging Practice-Principles of Timber Hravesting Systems. Miller Freeman Publications, inc. USA 
MacDonald, A. J. (1999). Harvesting System and Equipment in British Columbia. Forest Engineering Research Institute of Canada. Victoria, BC V8W 3E7

Manual Stihl 070, 090

Manual Stihl MS 381

Sessions, Johon. (2007). Harvesting Operations in the Tropics. Springer. Corvallis. 